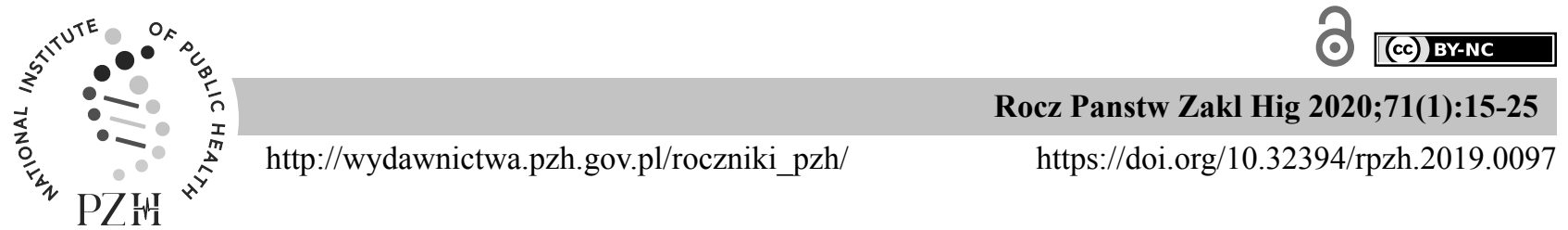

\title{
FRUIT AND VEGETABLES INTAKE IN ADOLESCENTS AND MENTAL HEALTH: A SYSTEMATIC REVIEW ${ }^{1)}$
}

\author{
Dominika Gtabska', Dominika Guzek²,Barbara Groele ${ }^{1}$, Krystyna Gutkowska² \\ ${ }^{1}$ Department of Dietetics, Institute of Human Nutrition, \\ Warsaw University of Life Sciences-SGGW, Warsaw, Poland \\ ${ }^{2}$ Department of Food Market and Consumer Research, Institute of Human Nutrition, \\ Warsaw University of Life Sciences-SGGW, Warsaw, Poland
}

\begin{abstract}
Background. The proper nutrition is indicated as a factor of a potential importance for the mental health early in life span, and among the potential products, which may influence, there are fruit and vegetables.

Objective. The aim of the study was to conduct a systematic review of the observational studies analyzing the association between the fruit and vegetables intake and the mental health in adolescents.

Material and methods. On the basis of PubMed and Web of Science databases, the papers presenting human studies and published in English until June 2019, analyzing the association between intake of fruit and/ or vegetables, as well as related products (e.g. juices) and the mental health were included to the systematic review, while they analyzed a group of adolescents.

Results. Based on the conducted systematic review, 17 studies were indicated as those which assess the influence of fruit and vegetables intake on the mental health in adolescents. For the assessment of mental health, diverse variables were taken into account, including positive (happiness, self-esteem), neutral (health-related quality of life, mental health status), and negative ones (loneliness, general difficulties, feeling worried, anxiety, stress and distress, depressive symptoms, depression, suicidal behaviors).

Conclusions. Based on the conducted systematic review of observational studies, it may be indicated that in a groups of adolescents there was a positive association between intake of fruit and vegetable products and mental health. Especially beneficial for general mental health in adolescents, were such products as green vegetables, yellow vegetables and fresh fruit.
\end{abstract}

Key words: fruit, vegetables, juices, mental health, adolescents, diet

\section{STRESZCZENIE}

Wprowadzenie. Prawidłowe żywienie jest wskazywane jako potencjalny czynnik, który może przyczyniać się do kształtowania zdrowia psychicznego we wczesnym okresie życia, a wśród produktów których spożycie może odgrywać największe znaczenie, znajdują się warzywa i owoce.

Cel badań. Celem badań było przeprowadzenie systematycznego przeglądu badań obserwacyjnych dotyczących zależności między spożyciem warzyw i owoców a zdrowiem psychicznym u młodzieży.

Material i metody. Dokonano przeglądu systematycznego baz PubMed i Web of Science, w którym włączono badania z udziałem ludzi, które były opublikowane do czerwca 2019 roku w języku angielskim i obejmowały ocenę, w grupie młodzieży, zależności między spożyciem warzyw i/ lub owoców (w tym przetworów, takich jak soki) a zdrowiem psychicznym. Wyniki. W oparciu o przeprowadzony przegląd piśmiennictwa, do analizy włączono 17 badań, oceniających zależność między spożyciem warzyw i owoców przez młodzież a ich zdrowiem psychicznym. W ocenie zdrowia psychicznego wykorzystano różnorodne czynniki, w tym te pozytywne (szczęście, poczucie własnej wartości), neutralne (jakość życia związana ze zdrowiem, status zdrowia psychicznego), i negatywne (samotność, generalne trudności, zmartwienie, niepokój, stres, objawy depresyjne, depresja, zachowania samobójcze).

Wnioski. W oparciu o przeprowadzony przegląd systematyczny badań obserwacyjnych, można wskazać, że w przypadku młodzieży spożycie produktów z grupy warzyw i owoców ma pozytywny wpływ na zdrowie psychiczne. Szczególnie pozytywny wpływ obserwowano dla zielonych warzyw, żółtych warzyw oraz świeżych owoców.

Słowa kluczowe: owoce, warzywa, soki, zdrowie psychiczne, młodzież, dieta

\footnotetext{
${ }^{1)}$ The study was financed by the Certified Product 'CP' Quality System (CEN.DRR.WFP.705.350.2018.MR.3) within the National Polish Promotion Fund for Fruits and Vegetables Consumption.
}

Corresponding author: Dominika Głąbska, Department of Dietetics, Institute of Human Nutrition, Warsaw University of Life Sciences-SGGW, Nowoursynowska Street 159c, 02-776 Warsaw, Poland, phone: +48 22 5937126, fax: +48 22 5937018, e-mail: dominika_glabska@sggw.pl 


\section{INTRODUCTION}

The age-of-onset worldwide distribution of mental health problems indicate that they commonly begin in the period of adolescence, while even $10-20 \%$ of adolescents experience such disorders [12]. It results from a multiple determinants of general mental health being associated with this specific period of life, such as developing own autonomy, self-control, social interactions, and learning, as well as possible social problems and their emotional consequences, including family conflicts at home and school bulling [27]. Based on the Health Behaviour in School-aged Children (HBSC) survey [3], conducted in United Kingdom, it was specified that in the age group of 1115 years old, $26 \%$ of adolescents declared "feeling low" at least once a week, while for girls it was even declared by $34 \%$ of respondents. Similarly, within the National Comorbidity Survey-Adolescent Supplement (NCS-A) survey [16], conducted in United States of America, it was observed that in the age group of 1318 years old, general prevalence of disorders with severe impairment and/ or distress was $22 \%$, while the Diagnostic and Statistical Manual of Mental Disorders, 4th Edition (DSM-IV) criteria were applied for diagnosis.

Taking it into account, as well as, emphasizing that currently suicide is the third leading cause of death in the age group of 15-19 years old, World Health Organization (WHO) formulated the statement, that there is a need for mental health promotion and prevention, combined with early detection and treatment of detected mental health problems in this age group [28]. Within a WHO Mental Health Gap Action Programme (mhGAP) [26], a broad area of actions that should be taken for an effective prevention was specified, including those associated not only with the government policy of reducing poverty and its consequences, promoting education, enhancing equity, gender equality and preventing violence, but also those associated with promoting proper nutrition.

The proper nutrition is indicated as a factor of a potential importance for the mental health early in life span, that was confirmed for the specific dietary patterns in the systematic review by O'Neil et al. [20]. However, the dietary patterns, being defined as the overall characteristics of diet, including the food products, food groups, and nutrients, with their combination and variety, as well as frequency and quantity with which they are habitually consumed, must be afterwards translated into nutritional recommendation, to obtain a specific preventive aim [4]. To formulate the precise guidelines, there is a need to specify the influence of detailed food products, or food groups, so it is necessary to verify which foods within the dietary pattern in fact influence the mental health.
Among the potential products, which may be associated with general mental health, there are fruit and vegetables. Not only the intake of fruit and vegetables in respondents with mental health problems is lower than recommended [19, 22], but also the association between intake and mental status is stated. In a group of male young adults it was proven that higher fruit and vegetables intake was a significant predictor of reduced risk of depression [24]. Similarly, in a group of young adults higher intake of raw fruit and vegetables predicted reduced risk of depressive symptoms, as well as higher positive mood, life satisfaction, and flourishing, but intake of processed fruit and vegetables predicted higher positive mood only [2]. While analyzing the presented results, that were observed for young adults, it may be supposed, that not only fruit and vegetables may be a positive dietary factors promoting a mental health, but also that the similar influence may be observed for younger age group. Taking it into account, the aim of the presented study was to conduct a systematic review of the observational studies analyzing the association between the fruit and vegetables intake and the mental health in adolescents.

\section{MATERIAL AND METHODS}

The peer-reviewed papers published in English language until June 2019, presenting the results of observational studies, were included to a systematic review. They were included based on PubMed and Web of Science databases, with additional manual searching of the references lists from the included studies. The search strategy applied to select the studies for the systematic review is presented in Table 1.

Based on the titles of the papers, two researchers, independently, selected studies, while in this stage they excluded only those which based on the title may have been with no doubts interpreted as not being within the inclusion criteria. Afterwards, in the second stage, those two researchers, also independently, verified inclusion based on the abstract, while they excluded only those which may have been with no doubts interpreted as not being within the inclusion criteria. In the last stage, based on the extracted full text, the final assessment was made. If any disagreement appeared and researchers did not have consistent conclusion after their discussion, the opinion of the third researcher was decisive.

The following inclusion criteria were applied while the studies were included to the systematic review:

- human studies,

- populations of healthy individuals and individuals with defined chronic or acute diseases,

- studied group of adolescents, or general population, but with adolescents analyzed separately as a subgroup, 
- habitual dietary intake assessed with the intake of fruit and/ or vegetables specified,

- any aspect of mental health assessed.

The following exclusion criteria were applied while the studies were included to the systematic review:

- experimental intervention studies,

- studied groups of individuals with intellectual disabilities diagnosed,

- studied groups of individuals with dementia diagnosed,

- studied groups of individuals with Attention Deficit Hyperactivity Disorder (ADHD) diagnosed,

- studied groups of individuals with eating disorders diagnosed,

- studies defining the influence of mental health on intake (the reverse association).

While the studies were included, the broad areas of aspects associated with fruit and/ or vegetables intake, as well as mental health were allowed. Both studies associated with the dietary intake assessed using dietary records, recalls, or food frequency questionnaires, and those associated with the dietary patterns including the increased share of fruit and/ or vegetables, were taken into account. Studies including juices and other processed fruit and/ or vegetable products were also accepted, but not those with a highly processed products, such as ketchup, or jam. Similarly, for the mental health, all the aspects were allowed, including both positive (e.g. happiness) and negative ones (e.g. depression). The procedure of including studies to the systematic review is presented as a flow chart, in Figure 1.

After the studies were verified and included after third stage of assessment (based on the full text of the paper), the following information were extracted from each publication: author, country/location, study group, number of participants, gender proportions, age, method of assessment of fruit and vegetable intake, other fruit and vegetable products included, method of outcome assessment, psychological measure, observations, and conclusions. Based on the indicated information, the narrative review was prepared, while the data for each paper included to the systematic review were organized in tables.

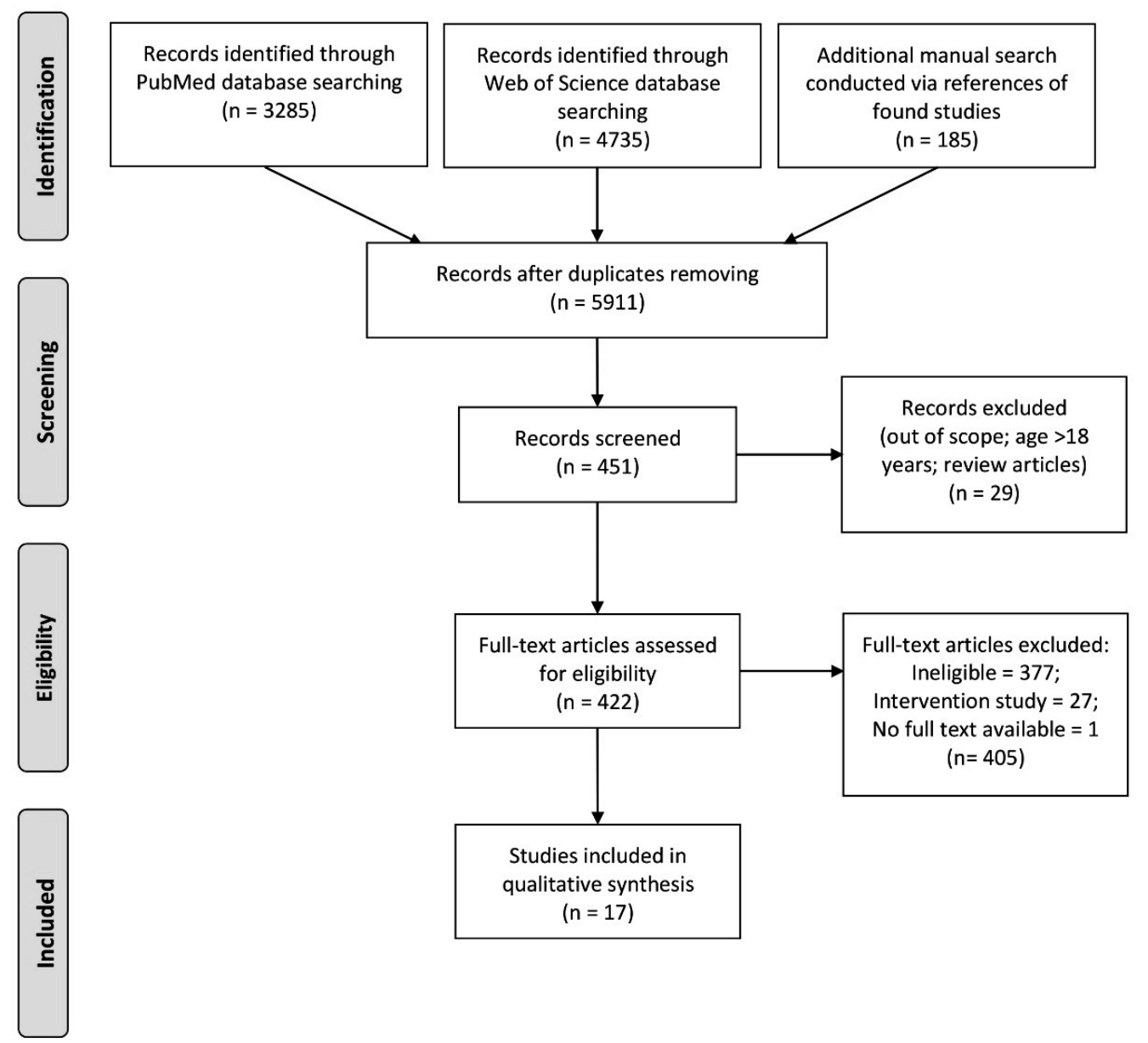

Figure 1. The flow chart presenting the procedure of including studies to the systematic review to assess the influence of fruit and vegetables intake on the mental health in adolescents 
Table 1. The search strategy applied to select the studies for the systematic review to assess the influence of fruit and vegetables intake on the mental health in adolescents

\begin{tabular}{|l|l|}
\hline Database & The applied full electronic search strategy \\
\hline PubMed & $\begin{array}{l}\text { ((fruit[Title/Abstract] OR fruits[Title/Abstract] OR vegetable[Title/Abstract] OR vegetables[Title/ } \\
\text { Abstract] OR juice[Title/Abstract] OR juices[Title/Abstract])) AND (mental health[Title/Abstract] OR } \\
\text { mental disorder[Title/Abstract] OR mental disorders[Title/Abstract] OR psychological distress[Title/ } \\
\text { Abstract] OR mood disorders[Title/Abstract] OR depression[Title/Abstract] OR anxiety[Title/ } \\
\text { Abstract] OR suicide[Title/Abstract] OR suicidal[Title/Abstract] OR well-being[Title/Abstract] } \\
\text { OR wellbeing[Title/Abstract] OR quality of life[Title/Abstract] OR self-esteem[Title/Abstract] OR } \\
\text { self esteem[Title/Abstract] OR self-efficacy[Title/Abstract] OR self efficacy[Title/Abstract] OR } \\
\text { resilience[Title/Abstract] OR empowerment[Title/Abstract] OR life skills[Title/Abstract] OR social } \\
\text { participation[Title/Abstract] OR mental capital[Title/Abstract] OR emotional[Title/Abstract] OR } \\
\text { psychosocial[Title/Abstract] OR psychology[Title/Abstract] OR psychiatry[Title/Abstract])) NOT } \\
\text { (animal NOT (animal AND human)[MeSH Terms]) }\end{array}$ \\
\hline $\begin{array}{l}\text { Web of } \\
\text { Science }\end{array}$ & $\begin{array}{l}\text { ORS "(fruit OR fruits OR vegetable OR vegetables OR juice OR juices) AND TS=("mental health" } \\
\text { depression OR anxiety OR suicide OR suicidal OR well-being OR wellbeing OR "quality of life" OR } \\
\text { self-esteem OR “self esteem" OR self-efficacy OR "self efficacy" OR resilience OR empowerment } \\
\text { OR "life skills" OR "social participation" OR "mental capital" OR emotional OR psychosocial OR } \\
\text { psychology OR psychiatry) NOT TS=(animal NOT (animal AND human))) }\end{array}$ \\
\hline
\end{tabular}

\section{RESULTS}

Based on the conducted systematic review, 17 studies were indicated as those which assess the influence of fruit and vegetables intake on the mental health in adolescents, as presented in Table 2.

The characteristics of the included studies verifying the influence of fruit and vegetables intake on the mental health in adolescents, for the applied method of fruit and vegetable dietary intake assessment and analyzed outcome associated with mental health is presented in Table 3.

The characteristics of the included studies verifying the influence of fruit and vegetables intake on the mental health in adolescents, for the results and conclusions is presented in Table 4 .

Table 2. The basic characteristics of the included studies verifying the influence of fruit and vegetables intake on the mental health in adolescents, for the country, studied group, sample size and age characteristics

\begin{tabular}{|c|c|c|c|c|c|}
\hline $\begin{array}{l}\text { Ref } \\
\text { No }\end{array}$ & Author, year & Country/ Location & $\begin{array}{l}\text { Studied group of } \\
\text { adolescents }\end{array}$ & $\begin{array}{l}\text { Number of patients } \\
\text { (number of girls) }\end{array}$ & Age \\
\hline$[1]$ & Arat, 2017 & $\begin{array}{l}\text { Botswana, Kenya, the } \\
\text { Seychelles, Uganda, } \\
\text { the United Republic of } \\
\text { Tanzania, Zambia }\end{array}$ & $\begin{array}{l}\text { Global School- } \\
\text { Based Health Survey } \\
\text { participants aged } \\
11-17 \text { years }\end{array}$ & $14,968(7,704)$ & $11-17$ years \\
\hline$[5]$ & $\begin{array}{l}\text { Ferrer-Cascales et al., } \\
2019\end{array}$ & Spain/ Alicante & High school students & $527(287)$ & $14.43 \pm 1.52$ years \\
\hline$[6]$ & Glozah et al. 2018 & Ghana & $\begin{array}{l}\text { Students younger } \\
\text { than } 18 \text { years }\end{array}$ & $1,984(908)$ & $\begin{array}{l}\text { Median of } 15 \\
\text { years }\end{array}$ \\
\hline [7] & Hong \& Peltzer, 2017 & South Korea & $\begin{array}{l}\text { Middle and high } \\
\text { school students }\end{array}$ & $65,212(31,725)$ & $15.1 \pm 0.02$ years \\
\hline [8] & Huang et al. 2019 & $\begin{array}{l}\text { United Kingdom/ } \\
\text { London }\end{array}$ & $\begin{array}{l}\text { Secondary school } \\
\text { students }\end{array}$ & $4,683(2,135)$ & $14-16$ years \\
\hline [9] & Jacka et al. 2011 & $\begin{array}{l}\text { Australia/ Barwon- } \\
\text { South Western region of } \\
\text { Victoria }\end{array}$ & $\begin{array}{l}\text { Secondary school } \\
\text { students }\end{array}$ & $2,915(1,283)$ & $\begin{array}{l}11-18 \text { years at } \\
\text { baseline }\end{array}$ \\
\hline [10] & Jacka et al. 2010 & Australia & $\begin{array}{l}\text { Australian Healthy } \\
\text { Neighbourhoods } \\
\text { Study participants } \\
\text { aged } 10-14 \text { years }\end{array}$ & $7,114(3,719)$ & $11.6 \pm 0.81$ years \\
\hline [11] & Jacka et al. 2013 & $\begin{array}{l}\text { United Kingdom/ East } \\
\text { London }\end{array}$ & $\begin{array}{l}\text { Socially deprived } \\
\text { young people }\end{array}$ & $2,789(1,433)$ & $\begin{array}{l}11-12 \text { years and } \\
13-14 \text { years }\end{array}$ \\
\hline
\end{tabular}




\begin{tabular}{|c|c|c|c|c|c|}
\hline $\begin{array}{l}\text { Ref } \\
\text { No }\end{array}$ & Author, year & Country/ Location & $\begin{array}{l}\text { Studied group of } \\
\text { adolescents }\end{array}$ & $\begin{array}{l}\text { Number of patients } \\
\text { (number of girls) }\end{array}$ & Age \\
\hline [13] & Khayyatzadeh et al. 2019 & $\begin{array}{l}\text { Iran/ Mashhad and } \\
\text { Sabzevar }\end{array}$ & Adolescent girls & $670(670)$ & $14.5 \pm 1.5$ years \\
\hline$[14]$ & Kim et al. 2015 & South Korea & Adolescent girls & 849 (849) & $15.0 \pm 1.5$ years \\
\hline$[15]$ & Kristjánsson et al., 2010 & Iceland & $\begin{array}{l}\text { Secondary school } \\
\text { students }\end{array}$ & $5,810(3,004)$ & $14-15$ years \\
\hline$[17]$ & Oddy et al., 2018 & Western Australia & $\begin{array}{l}\text { Raine Study } \\
\text { participants }\end{array}$ & $843(429)$ & $\begin{array}{l}14 \text { and } 17 \text { years } \\
\text { at data gathering }\end{array}$ \\
\hline$[18]$ & Oddy et al, 2009 & Western Australia & $\begin{array}{l}\text { Raine Study } \\
\text { participants }\end{array}$ & $1,598(779)$ & $14.01 \pm 0.2$ years \\
\hline$[21]$ & Park et al. 2018 & South Korea & $\begin{array}{l}\text { Middle- and high- } \\
\text { school students }\end{array}$ & $65,528(31,725)$ & $14.99 \pm 1.74$ years \\
\hline$[23]$ & $\begin{array}{l}\text { Tanaka \& Hashimoto, } \\
2019\end{array}$ & $\begin{array}{l}\text { Japan/ Fukuoka } \\
\text { prefecture }\end{array}$ & $\begin{array}{l}\text { Junior and senior } \\
\text { high school students }\end{array}$ & $858(496)$ & $15.49 \pm 1.78$ years \\
\hline$[25]$ & Weng et al. 2011 & China/ Bengbu city & $\begin{array}{l}\text { Junior high school } \\
\text { students }\end{array}$ & $5,003(2,397)$ & $13.21 \pm 0.99$ years \\
\hline [29] & Winpenny et al. 2018 & $\begin{array}{l}\text { United Kingdom / } \\
\text { Cambridgeshire and } \\
\text { Suffolk }\end{array}$ & $\begin{array}{l}\text { Secondary school } \\
\text { students }\end{array}$ & $603(362)$ & $14.5 \pm 0.3$ years \\
\hline
\end{tabular}

Table 3. The characteristics of the included studies verifying the influence of fruit and vegetables intake on the mental health in adolescents, for the applied method of fruit and vegetable dietary intake assessment and analyzed outcome associated with mental health

\begin{tabular}{|c|c|c|c|c|}
\hline $\begin{array}{l}\text { Ref } \\
\text { No }\end{array}$ & $\begin{array}{l}\text { Applied method of fruit } \\
\text { and vegetable dietary } \\
\text { intake assessment }\end{array}$ & $\begin{array}{l}\text { Potentially included } \\
\text { juices and other fruit/ } \\
\text { vegetable products }\end{array}$ & Assessed outcome & Psychological measure of outcome \\
\hline [1] & $\begin{array}{l}\text { Question about number of } \\
\text { portions }\end{array}$ & - & $\begin{array}{l}\text { (1) Suicidal ideation } \\
\text { (2) Suicide plan } \\
\text { (3) Suicide attempts } \\
\text { (4) Loneliness } \\
\text { (5) Anxiety } \\
\text { (6) Depression }\end{array}$ & $\begin{array}{l}\text { (1) Question about seriously considering } \\
\text { attempting suicide during the past } 12 \\
\text { months } \\
\text { (2) Question about making a plan about } \\
\text { how they would attempt suicide during } \\
\text { the past } 12 \text { months } \\
\text { (3) Question about suicide attempts } \\
\text { during the past } 12 \text { months } \\
\text { (4) Question about frequency of feeling } \\
\text { lonely during the past } 12 \text { months } \\
\text { (5) Question about frequency of being } \\
\text { so worried about something that they } \\
\text { could not sleep at night during the past } 12 \\
\text { months } \\
\text { (6) Question about feeling so sad or } \\
\text { hopeless almost every day for } 2 \text { weeks } \\
\text { or more in a row that they stopped doing } \\
\text { their usual activities during the past } 12 \\
\text { months }\end{array}$ \\
\hline [5] & $\begin{array}{l}\text { The Mediterranean Diet } \\
\text { Quality Index for children } \\
\text { and teenagers (KIDMED) } \\
\text { questionnaire }\end{array}$ & - & $\begin{array}{l}\text { (1) Happiness } \\
\text { (2) Health-related } \\
\text { quality of life } \\
\text { (HRQOL) }\end{array}$ & $\begin{array}{l}\text { (1) The Subjective Happiness Scale } \\
\text { (SHS) } \\
\text { (2) The KIDSCREEN-52 }\end{array}$ \\
\hline [6] & $\begin{array}{l}\text { Question about frequency } \\
\text { of consumption }\end{array}$ & - & $\begin{array}{l}\text { (1) Feeling lonely } \\
\text { (2) Feeling worried } \\
\text { (3) Suicidal ideation }\end{array}$ & $\begin{array}{l}\text { (1) Question about frequency of feeling } \\
\text { lonely during the past } 12 \text { months } \\
\text { (2) Question about frequency of feeling } \\
\text { worried about something that they could } \\
\text { not sleep at night during the past } 12 \\
\text { months } \\
\text { (3) Question about making a plan about } \\
\text { how they would attempt suicide during } \\
\text { the past } 12 \text { months }\end{array}$ \\
\hline
\end{tabular}




\begin{tabular}{|c|c|c|c|c|}
\hline $\begin{array}{l}\text { Ref } \\
\text { No }\end{array}$ & $\begin{array}{l}\text { Applied method of fruit } \\
\text { and vegetable dietary } \\
\text { intake assessment }\end{array}$ & $\begin{array}{l}\text { Potentially included } \\
\text { juices and other fruit/ } \\
\text { vegetable products }\end{array}$ & Assessed outcome & Psychological measure of outcome \\
\hline$[7]$ & $\begin{array}{l}\text { Questions about } \\
\text { frequency of engaging in } \\
\text { dietary behaviors }\end{array}$ & $\begin{array}{l}\text { Fruit juice excluded } \\
\text { Vegetable dishes } \\
\text { (excluding Kimchi) } \\
\text { included }\end{array}$ & $\begin{array}{l}\text { (1) Perceived } \\
\text { happiness } \\
\text { (2) Perceived stress } \\
\text { (3) Depression } \\
\text { symptoms }\end{array}$ & $\begin{array}{l}\text { (1) Question about how happy do they } \\
\text { usually feel } \\
\text { (2) Question about to what degree are } \\
\text { they usually stressed } \\
\text { (3) Question about experienced sadness } \\
\text { or despair to the degree that stopped their } \\
\text { daily routine for the recent } 12 \text { months }\end{array}$ \\
\hline$[8]$ & $\begin{array}{l}\text { Validated question about } \\
\text { number of portions }\end{array}$ & - & $\begin{array}{l}\text { Total Difficulties } \\
\text { Score (TDS) }\end{array}$ & $\begin{array}{l}\text { Strengths and Difficulties Questionnaire } \\
\text { (SDQ) }\end{array}$ \\
\hline [9] & $\begin{array}{l}\text { Questions about frequency } \\
\text { of consumption, to } \\
\text { assess the Alternative } \\
\text { Healthy Eating Index, the } \\
\text { Mediterranean Index and } \\
\text { Unhealthy Diet Score }\end{array}$ & - & $\begin{array}{l}\text { Depressive } \\
\text { symptoms }\end{array}$ & $\begin{array}{l}\text { Pediatric Quality of Life Inventory } \\
\text { (PedsQL) }\end{array}$ \\
\hline [10] & $\begin{array}{l}\text { 14-item dietary } \\
\text { questionnaire, to assess } \\
\text { the healthy diet score and } \\
\text { unhealthy diet score }\end{array}$ & - & Depression & $\begin{array}{l}\text { Short Mood and Feelings Questionnaire } \\
\text { (SMFQ) }\end{array}$ \\
\hline [11] & $\begin{array}{l}\text { Question about number } \\
\text { of portions, to assess the } \\
\text { healthy diet score and } \\
\text { unhealthy diet score }\end{array}$ & - & $\begin{array}{l}\text { (1) Psychological } \\
\text { distress } \\
\text { (2) Depressive } \\
\text { symptoms }\end{array}$ & $\begin{array}{l}\text { (1) Strengths and Difficulties } \\
\text { Questionnaire (SDQ) } \\
\text { (2) Short Moods and Feelings } \\
\text { Questionnaire (SMFQ) }\end{array}$ \\
\hline [13] & $\begin{array}{l}\text { Food frequency } \\
\text { questionnaire with } 147 \\
\text { food items, to indicate } \\
\text { "Healthy", "Traditional" } \\
\text { and "Western" dietary } \\
\text { pattern }\end{array}$ & $\begin{array}{l}\text { Lemon juice, other types } \\
\text { of juice, industrial juice } \\
\text { and fruit compote, dried } \\
\text { fruits, tomato sauce } \\
\text { included }\end{array}$ & Depression severity & Beck depression inventory (BDI-II) \\
\hline [14] & $\begin{array}{l}\text { Food frequency } \\
\text { questionnaire with } 63 \\
\text { food items }\end{array}$ & - & Depression & $\begin{array}{l}\text { Korean version of the Beck Depression } \\
\text { Inventory (K-BDI) }\end{array}$ \\
\hline [15] & $\begin{array}{l}\text { Question about frequency } \\
\text { of consumption }\end{array}$ & - & Self-esteem & Rosenberg Self-Esteem Scale \\
\hline [17] & $\begin{array}{l}\text { Food frequency } \\
\text { questionnaire with } 212 \\
\text { food items, to indicate } \\
\text { "Healthy" and "Western" } \\
\text { dietary pattern }\end{array}$ & - & $\begin{array}{l}\text { (1) Depression } \\
\text { (2) Other } \\
\text { internalising and } \\
\text { externalising } \\
\text { mental health } \\
\text { problems }\end{array}$ & $\begin{array}{l}\text { (1) Beck Depression Inventory for Youth } \\
\text { (BDI-Y) } \\
\text { (2) Youth Self Report (YSR) }\end{array}$ \\
\hline [18] & $\begin{array}{l}\text { Food frequency } \\
\text { questionnaire with } 212 \\
\text { food items, to indicate } \\
\text { "Healthy" and "Western" } \\
\text { dietary pattern }\end{array}$ & $\begin{array}{l}\text { Fruit canned in syrup or } \\
\text { juice, pure fruit juice, } \\
\text { vegetable juice, cordial } \\
\text { fruit drink ( } \leq 35 \% \text { fruit } \\
\text { juice) included }\end{array}$ & Mental health status & Child Behavior Checklist (CBCL/4-18) \\
\hline [21] & $\begin{array}{l}\text { Questions about } \\
\text { frequency of engaging in } \\
\text { dietary behaviors }\end{array}$ & Fruit juice excluded & $\begin{array}{l}\text { (1) Perceived stress } \\
\text { (2) Self-perceived } \\
\text { happiness }\end{array}$ & $\begin{array}{l}\text { (1) Question about to what degree are } \\
\text { they usually stressed } \\
\text { (2) Question about how happy do they } \\
\text { usually feel }\end{array}$ \\
\hline [23] & $\begin{array}{l}\text { Question about number of } \\
\text { portions }\end{array}$ & - & $\begin{array}{l}\text { Depressive } \\
\text { symptoms }\end{array}$ & $\begin{array}{l}\text { Center for Epidemiologic Studies } \\
\text { Depression scale (CES-D) }\end{array}$ \\
\hline [25] & $\begin{array}{l}\text { Self-administered food } \\
\text { frequency questionnaire } \\
\text { with } 38 \text { food items, to } \\
\text { indicate "Snack", "Animal } \\
\text { food" and "Traditional" } \\
\text { dietary pattern }\end{array}$ & $\begin{array}{l}\text { Fruit and vegetable } \\
\text { juices, preserved fruit } \\
\text { (prunes, raisins) included }\end{array}$ & $\begin{array}{l}\text { (1) Depression } \\
\text { symptoms } \\
\text { (2) Anxiety } \\
\text { symptoms }\end{array}$ & $\begin{array}{l}\text { (1) Chinese version of the Depression } \\
\text { Self-rating Scale for Children (DSRS) } \\
\text { (2) Chinese version of the Screen Scale } \\
\text { for Child Anxiety Related Emotional } \\
\text { Disorders (SCARED) }\end{array}$ \\
\hline
\end{tabular}




\begin{tabular}{|c|l|l|l|l|}
\hline $\begin{array}{c}\text { Ref } \\
\text { No }\end{array}$ & $\begin{array}{c}\text { Applied method of fruit } \\
\text { and vegetable dietary } \\
\text { intake assessment }\end{array}$ & $\begin{array}{c}\text { Potentially included } \\
\text { juices and other fruit/ } \\
\text { vegetable products }\end{array}$ & Assessed outcome & Psychological measure of outcome \\
\hline$[29]$ & $\begin{array}{l}\text { 4-days dietary record, to } \\
\text { assess Mediterranean } \\
\text { Diet Score (MDS) }\end{array}$ & - & $\begin{array}{l}\text { Depressive } \\
\text { symptoms, } \\
\text { including low } \\
\text { mood, loss of } \\
\text { appetite, } \\
\text { anhedonia, } \\
\text { irritability and } \\
\text { restlessness }\end{array}$ & $\begin{array}{l}\text { Moods and Feelings Questionnaire } \\
\text { (MFQ) }\end{array}$ \\
\hline
\end{tabular}

Table 4. The characteristics of the included studies verifying the influence of fruit and vegetables intake on the mental health in adolescents, for the results and conclusions

\begin{tabular}{|c|c|c|}
\hline $\begin{array}{l}\text { Ref } \\
\text { No }\end{array}$ & Results & Conclusions \\
\hline [1] & $\begin{array}{l}\text { Higher fruit intake was indicated as a risk factor for depression, anxiety } \\
\text { (except the United Republic of Tanzania), loneliness, suicidal ideation } \\
\text { (except Zambia and Uganda), and suicide attempts (except Botswana). } \\
\text { Higher fruit intake was indicated as a protective factor for suicide plan } \\
\text { (except Botswana). Higher vegetable consumption was indicated as a risk } \\
\text { factor for depression, anxiety (except the United Republic of Tanzania } \\
\text { and Zambia), loneliness, suicidal ideation, and suicide attempts. Higher } \\
\text { vegetable intake was indicated as a protective factor for suicide plan. }\end{array}$ & $\begin{array}{l}\text { Both high levels of fruit and higher } \\
\text { vegetable intake mostly predicted higher } \\
\text { likelihood of poor mental health. }\end{array}$ \\
\hline$[5]$ & $\begin{array}{l}\text { High Mediterranean diet adherence was related to high scores in subjective } \\
\text { happiness and each health-related quality of life dimension (physical well- } \\
\text { being, psychological well-being, moods and emotions, self-perception, } \\
\text { autonomy, parent relations, home life, financial resources, social support, } \\
\text { peers, school environment and social acceptance) (p }<0.001 \text {, in all cases). }\end{array}$ & $\begin{array}{l}\text { Results obtained show positive associations } \\
\text { of Mediterranean diet adherence with higher } \\
\text { levels of subjective happiness and better } \\
\text { health-related quality of life. }\end{array}$ \\
\hline$[6]$ & $\begin{array}{l}\text { "Ate vegetables } 3+\text { times per day past } 30 \text { days" was the only health } \\
\text { behavior that was significantly associated with suicidal ideation }(\mathrm{OR}= \\
0.71) \text { with youth who "ate vegetables } 3+\text { times per day past } 30 \text { days" being } \\
\text { less likely to experience suicidal ideation. After controlling for the effects } \\
\text { of socio-demographic characteristics "ate vegetables } 3+\text { times per day past } \\
30 \text { days" remained significant }(\mathrm{OR}=0.73) \text {. }\end{array}$ & $\begin{array}{l}\text { Poor dietary habits could have a negative } \\
\text { effect on mental distress. }\end{array}$ \\
\hline [7] & $\begin{array}{l}\text { In logistic regression analyses, adjusted for age, sex, socioeconomic } \\
\text { status, school level, school types, body mass index, physical activity, } \\
\text { and substance use, positive dietary behaviors (fruit and vegetable } \\
\text { consumption) were associated with self-reported happiness. Positive } \\
\text { dietary behaviors were negatively associated with perceived stress and } \\
\text { depression symptoms. }\end{array}$ & $\begin{array}{l}\text { Healthy dietary behaviors were associated } \\
\text { with lower mental distress and higher } \\
\text { psychological well-being. }\end{array}$ \\
\hline$[8]$ & $\begin{array}{l}\text { In fully adjusted models, }<1 \text { portion/day remained a significant correlate } \\
\text { with mean Total Difficulties Score (TDS) }(\text { Coef: } 0.55,0.29-0.81, \mathrm{p}< \\
0.001) \text { and TDS }>17 \text { (Odds Ratio: } 1.43,1.11-1.85, \mathrm{p}=0.007) .\end{array}$ & $\begin{array}{l}\text { Low fruit and vegetable intake is } \\
\text { a longitudinal correlate of poor mental } \\
\text { health across adolescence. }\end{array}$ \\
\hline [9] & $\begin{array}{l}\text { There were cross-sectional, dose response relationships identified between } \\
\text { measures of both healthy (positive) and unhealthy (inverse) diets and } \\
\text { scores on the emotional subscale of the Pediatric Quality of Life Inventory } \\
\text { (PedsQL), where higher scores mean better mental health, before and after } \\
\text { adjustments for age, gender, socio-economic status, dieting behaviors, body } \\
\text { mass index and physical activity. Higher healthy diet scores at baseline also } \\
\text { predicted higher PedsQL scores at follow-up, while higher unhealthy diet } \\
\text { scores at baseline predicted lower PedsQL scores at follow-up. }\end{array}$ & $\begin{array}{l}\text { Improvements in diet quality were mirrored } \\
\text { by improvements in mental health over } \\
\text { the follow-up period, while deteriorating } \\
\text { diet quality was associated with poorer } \\
\text { psychological functioning. }\end{array}$ \\
\hline [10] & $\begin{array}{l}\text { Compared to the lowest category of the healthy diet score, the adjusted } \\
\text { odds ratios }(95 \% \text { confidence interval) for symptomatic depression } \\
\text { across categories }(\mathrm{C}) \text { was: } \mathrm{C} 2=0.61(0.45-0.84) ; \mathrm{C} 3=0.58(0.43-0.79) \text {; } \\
\mathrm{C} 4=0.47(0.35-0.64) \text {; and } \mathrm{C} 5=0.55(0.40-0.77) \text {. Compared to the } \\
\text { lowest quintile, the adjusted odds ratios }(95 \% \text { confidence interval) for } \\
\text { symptomatic depression across increasing quintiles of the unhealthy diet } \\
\text { score were: } \mathrm{Q} 2=1.03(0.87-1.22) ; \mathrm{Q} 3=1.22(1.03-1.44) ; \mathrm{Q} 4=1.29 \\
(1.12-1.50) \text {; and Q5 }=1.79(1.52-2.11) \text {. }\end{array}$ & $\begin{array}{l}\text { There is an association between diet quality } \\
\text { and adolescent depression that exists over } \\
\text { and above the influence of socioeconomic, } \\
\text { family, and other potential confounding } \\
\text { factors. }\end{array}$ \\
\hline
\end{tabular}




\begin{tabular}{|c|c|c|}
\hline $\begin{array}{l}\text { Ref } \\
\text { No }\end{array}$ & Results & Conclusions \\
\hline [11] & $\begin{array}{l}\text { Compared to those in the lowest quintile of unhealthy diet score, those } \\
\text { in the highest quintile were more than twice as likely to be symptomatic } \\
\text { on the Strengths and Difficulties Questionnaire (SDQ) (OR } 2.10,95 \% \\
\text { CI } 1.38-3.20 \text { ) after taking all identified confounders into account. There } \\
\text { was also some evidence for a cross-sectional inverse association between } \\
\text { a measure of healthy diet and mental health problems. A prospective } \\
\text { relationship between the highest quintiles of both healthy (OR } 0.63,95 \\
\% \text { CI } 0.38-1.05 \text { ) and unhealthy (OR } 1.75,95 \% \text { CI } 1.00-3.06) \text { diet scores } \\
\text { and SDQ scores at follow-up was also evident, but was attenuated by final } \\
\text { adjustments for confounders. }\end{array}$ & $\begin{array}{l}\text { There is the evidence for an association } \\
\text { between an unhealthy diet and mental health } \\
\text { problems. }\end{array}$ \\
\hline [13] & $\begin{array}{l}\text { The multivariate-adjusted odds ratio of having depressive symptoms } \\
\text { was } 0.55 \text { ( } 95 \% \text { CI } 0.34-0.89) \text { for the highest versus lowest quartile of } \\
\text { the healthy dietary pattern score. However, there were no significant } \\
\text { associations between the "Traditional" and "Western" dietary patterns and } \\
\text { depression symptoms. }\end{array}$ & $\begin{array}{l}\text { Adherence to a "Healthy" dietary pattern } \\
\text { characterized by high intakes of fruits, } \\
\text { vegetables, fish and dairy products is } \\
\text { associated with a lower probability of } \\
\text { having depressive symptoms among Iranian } \\
\text { adolescent girls. }\end{array}$ \\
\hline [14] & $\begin{array}{l}\text { Multivariate adjusted regression analysis demonstrated that the risk of } \\
\text { depression was significantly negatively associated with the intake of green } \\
\text { vegetables and } 1 \text { to } 3 \text { servings/day of fruits, after adjusting for energy } \\
\text { intake and menstrual regularity. }\end{array}$ & $\begin{array}{l}\text { Low intake of green vegetables and fruits } \\
\text { were associated with increased risk of } \\
\text { depression in Korean adolescent girls. }\end{array}$ \\
\hline [15] & $\begin{array}{l}\text { Self-esteem was positively influenced by the consumption of fruits and } \\
\text { vegetables }(\beta=0.14) \text {. }\end{array}$ & $\begin{array}{l}\text { Poor dietary habits negatively and health } \\
\text { behavior positively influence self-esteem. }\end{array}$ \\
\hline [17] & $\begin{array}{l}\text { The "Western" dietary pattern at } 14 \text { years was associated with higher } \\
\text { energy intake and BMI at } 14 \text { years }(\mathrm{p}<0.05) \text {. A "Healthy" dietary pattern } \\
\text { (high in fruit, vegetables, fish, whole-grains) was inversely associated with } \\
\text { BMI and inflammation at } 17 \text { years }(\mathrm{p}<0.05) \text {. Higher BMI at } 14 \text { years was } \\
\text { associated with higher BMI }(\mathrm{p}<0.01) \text {, depressive symptoms }(\mathrm{p}<0.05) \\
\text { and mental health problems }(\mathrm{p}<0.05) \text { at } 17 \text { years. }\end{array}$ & $\begin{array}{l}\text { A "Western" dietary pattern associates } \\
\text { with an increased risk of mental health } \\
\text { problems including depressive symptoms in } \\
\text { adolescents, through biologically plausible } \\
\text { pathways of adiposity and inflammation, } \\
\text { whereas a "Healthy" dietary pattern appears } \\
\text { protective in these pathways. }\end{array}$ \\
\hline [18] & $\begin{array}{l}\text { Higher total }(b=2.20,95 \% \text { CI 1.06-3.35), internalizing (withdrawn/ } \\
\text { depressed) }(b=1.25,95 \% \text { CI } 0.15-2.35) \text { and externalizing (delinquent/ } \\
\text { aggressive) }(b=2.60,95 \% \text { CI 1.51-3.68) Child Behaviour Checklist } \\
\text { (CBCL) scores were significantly associated with the "Western" dietary } \\
\text { pattern. Improved behavioral scores were significantly associated with } \\
\text { higher intakes of leafy green vegetables and fresh fruit (components of the } \\
\text { "Healthy" pattern). }\end{array}$ & $\begin{array}{l}\text { Better behavioral outcomes were associated } \\
\text { with a higher intake of fresh fruit and leafy } \\
\text { green vegetables. }\end{array}$ \\
\hline [21] & $\begin{array}{l}\text { High intake of fruits and vegetables were associated with better self- } \\
\text { perceived happiness. }\end{array}$ & $\begin{array}{l}\text { Existing encouraged dietary habits mostly } \\
\text { have beneficial effects on perceived mental } \\
\text { health in Korean adolescents. }\end{array}$ \\
\hline [23] & $\begin{array}{l}\text { Negative and significant partial correlation was found between regular } \\
\text { consumption of green and yellow vegetables and depressive symptoms } \\
\text { in both junior and senior high school students, after controlling for age, } \\
\text { sex, and sleep duration. Furthermore, a one-way analysis of covariance } \\
\text { (ANCOVA) revealed that adolescents who consumed green and yellow } \\
\text { vegetables every day (one or more times per day) had significantly lower } \\
\text { depressive symptoms than those from the "Never/1-2 times a week" group. }\end{array}$ & $\begin{array}{l}\text { Regular consumption of green and yellow } \\
\text { vegetables is associated with lower } \\
\text { depressive symptoms in adolescents, that } \\
\text { is, the consumption of green and yellow } \\
\text { vegetables may be vital in the context of } \\
\text { adolescents' mental health. }\end{array}$ \\
\hline [25] & $\begin{array}{l}\text { Compared with low consumption, adolescents in the highest tertile of } \\
\text { traditional dietary pattern scores had lower odds for 'pure' depression (OR } \\
=0.38 ; 95 \% \text { CI } 0.30-0.49) \text {, 'pure' anxiety }(\mathrm{OR}=0.85 ; 95 \% \text { CI } 0.69-1.04) \\
\text { and coexisting anxiety and depression (OR }=0.50 ; 95 \% \text { CI } 0.39-0.63) \text {. }\end{array}$ & $\begin{array}{l}\text { Dietary patterns should be considered as } \\
\text { important predictors of depression and } \\
\text { anxiety. }\end{array}$ \\
\hline [29] & $\begin{array}{l}\text { At age } 14 \text { years, a negative association between fruit and vegetable intake } \\
\text { and Moods and Feelings Questionnaire (MFQ) score was seen in the } \\
\text { unadjusted cross-sectional regression model ( } \beta=-0.40 ; 95 \% \text { CI }-0.71 \text {, } \\
-0.10) \text {, but adjustment for behavioral covariates, including smoking } \\
\text { and alcohol consumption, attenuated this association. No prospective } \\
\text { associations were found between Mediterranean diet score (MDS), fruit } \\
\text { and vegetable intake and later MFQ score. }\end{array}$ & $\begin{array}{l}\text { Diet quality was not associated with } \\
\text { depressive symptoms in mid-adolescence. }\end{array}$ \\
\hline
\end{tabular}




\section{DISCUSSION}

Within the studies included to a systematic review, there were such of various sample size, as some of them assessed less than 1000 respondents $[5,13,14$, $17,23,29]$, but other studied large population-based groups, as in the case of almost 15,000 participants of Global School-Based Health Survey [1], or over 65,000 participants from South Korea, assessed in two studies [7,21]. Based on the presented data, it may be supposed that some of the included studies assessed populations which overlapped, as for indicated South Korean studies [7,21], but for the presented systematic review, they were treated as a separate analysis.

Included studies were conducted mainly in various Asian countries [7, 13, 14, 21, 23, 25], European countries [5, 8, 11, 15, 29], Australia [9, 10, 17, 18], but also Ghana [6] and combined population of the Botswana, Kenya, Seychelles, Uganda, Tanzania and Zambia [1]. The assessed participants were recruited mainly in a school-based manner $[5,6,7,8,9,15,21$, $23,25,29]$, while for majority of studies the samples were population-based, but also in case of one study, there was a specific group of socially deprived young people included [11].

Within included studies, fruit and vegetable dietary intake was assessed mainly using a simple question about the frequency of consumption, or about the number of portions in a specified period of time $[1,6,7$, $9,10,11,15,21,23]$, including the validated questions [8], or questionnaires [13, 14, 17, 8, 25]. However, for some studies, based on the obtained data, dietary patterns $[13,17,18,25]$, or diet quality indexes were specified $[9,10,11]$. But also the Mediterranean Diet Quality Index for children and teenagers (KIDMED), being a specific questionnaire, to assess the quality of diet within a specific Mediterranean pattern [5], and 4-days dietary record, to assess Mediterranean Diet Score (MDS) [29] were applied.

The majority of studies assessed only fruit and vegetables intake, with no specified information about potentially included juices and other fruit/ vegetable products, but some of them specified fruit juices as excluded [21], or fruit juices as excluded, but vegetable dishes as included [7]. At the same time, in some studies, specific juices and other products were analyzed, such as lemon juice, other types of juice, industrial juice and fruit compote, dried fruits, and tomato sauce [13], fruit canned in syrup or juice, pure fruit juice, vegetable juice, and cordial fruit drink ( $\leq 35 \%$ fruit juice) [18], or fruit and vegetable juices, preserved fruit (such as prunes, raisins) [25].

For the assessment of mental health, diverse variables were taken into account, both positive or negative, and neutral, such as health-related quality of life [5], or mental health status [18]. Among positive variables characterizing mental health, there were: happiness [5, 7, 21] and self-esteem [15], while among negative variables characterizing mental health, there were: loneliness [1, 6], general difficulties [8], feeling worried [6], anxiety [1,25], stress and distress [7, 11, 21], depressive symptoms [7, 9, 11, 23, 29], depression $[1,10,13,14,17,25]$, suicidal ideation $[1,6]$, suicidal plan [1], suicide attempts [1].

In all included studies a positive influence of fruit and vegetables intake $[6,8,15,21]$, or dietary patterns associated with higher intake of those products $[5,7$, $9,10,11,13,25]$, on mental health were confirmed, but for some of them the results were not consistent for all factors associated with mental health, or were not consistent in all analysis [1,29]. At the same time, based on analyzed studies, it may be supposed, that the association is not direct, but the dietary patterns influence body mass and body mass influences mental health [17].

Some studies allow to indicate especially beneficial products from the group of fruit and vegetables, such as green vegetables $[14,18,23]$, yellow vegetables [23] and fresh fruit [18]. Moreover, based on the included studies, the recommended frequency of fruit and vegetables consumption may be justified. It was stated, that consumption of less than 1 serving of fruit or vegetables per day was associated with a higher level of general difficulties [8]. At the same time, consumption at least 3 servings of vegetables per day during the previous 30 days was associated with lower experience of suicidal ideation [6].

\section{CONCLUSIONS}

Based on the conducted systematic review of observational studies, it may be indicated that in a groups of adolescents there was a positive association between intake of fruit and vegetable products and mental health. Especially beneficial for general mental health in adolescents, were green vegetables, yellow vegetables and fresh fruit.

\section{Acknowledgements}

The study was supported by the Certified Product 'CP' Quality System (CEN.DRR.WFP.705.350.2018. MR.3) within the National Polish Promotion Fund for Fruits and Vegetables Consumption. The funders had no role in the design of the study, in the collection, analyses, or interpretation of data, in the writing of the manuscript, or in the decision to publish the results. 


\section{REFERENCES}

1. Arat $G$. The link between nutrition and mental health in sub-Saharan African adolescents: findings from the global school-based health survey. Glob Soc Welf. 2017;4:31-40.

2. Brookie K.L., Best G.I., Conner T.S. Intake of raw fruits and vegetables is associated with better mental health than intake of processed fruits and vegetables. Front Psychol. 2018;10;9:487. doi: 10.3389/ fpsyg.2018.00487.

3. Brooks F., Magnusson J., Klemera E., Chester K., Spencer N., Smeeton N. HBSC England National Report 2014. University of Hertfordshire; Hatfield, UK, 2015.

4. Cespedes E.M., Hu F.B. Dietary patterns: from nutritional epidemiologic analysis to national guidelines. Am J Clin Nutr. 2015;101(5):899-900. doi:10.3945/ajcn.115.110213.

5. Ferrer-Cascales R. Albaladejo-Blazquez N., RuizRobledillo N., Clement-Carbonell V., SanchezSanSegundo M., Zaragoza-Marti A. Higher adherence to the Mediterranean diet is related to more subjective happiness in adolescents: the role of health-related quality of life. Nutrients. 2019; 25;11(3):e698. doi:10.3390/nu11030698.

6. Glozah F.N., Oppong Asante K., Kugbey N. Parental involvement could mitigate the effects of physical activity and dietary habits on mental distress in Ghanaian youth. PLoS One. 2018;17;13(5):e0197551. doi:10.1371/journal.pone.0197551.

7. Hong S.A, Peltzer K. Dietary behaviour, psychological well-being and mental distress among adolescents in Korea. Child Adolesc Psychiatry Ment Health. 2017;28;11:56. doi:10.1186/s13034-017-0194-z.

8. Huang P., O'Keeffe M., Elia C., Karamanos A., Goff L.M., Maynard M., Cruickshank J.K., Harding S. Fruit and vegetable consumption and mental health across adolescence: evidence from a diverse urban British cohort study. Int $\mathrm{J}$ Behav Nutr Phys Act. 2019;8;16(1):19. doi:10.1186/s12966-019-0780-y.

9. Jacka F.N., Kremer P.J., Berk M., de Silva-Sanigorski A.M., Moodie M., Leslie E.R., Pasco J.A., Swinburn $B$.A. A prospective study of diet quality and mental health in adolescents. PLoS One 2011;6:e24805.

10. Jacka F.N., Kremer P.J., Leslie E.R., Berk M., Patton G.C., Toumbourou J.W., Williams J.W. Associations between diet quality and depressed mood in adolescents: results from the Australian Healthy Neighbourhoods Study. Aust N Z J Psychiatry. 2010;44:435-442.

11. Jacka F.N., Rothon C., Taylor S., Berk M., Stansfeld S.A. Diet quality and mental health problems in adolescents from East London: a prospective study. Soc Psychiatry Psychiatr Epidemiol. 2013;48:1297-1306.

12. Kessler R.C., Angermeyer M., Anthony J.C., Graaf R. Demyttenaere K., Gasquet I., Girolamo G., Gluzman S., Gureje O., Haro J.M., Kawakami N., Karam A., Levinson D., Medina Mora M.E., Oakley Browne M.A., Posada-Villa J., Stein D.J., Adley Tsang C.H., AguilarGaxiola S., Alonso J., Lee S., Heeringa S., Pennell B.E., Berglund P., Gruber M.J., Petukhova M., Chatterji
S., Ustün T.B. Lifetime prevalence and age-of-onset distributions of mental disorders in the World Health Organization's World Mental Health Survey Initiative. World Psychiatry. 2007;6(3):168-176.

13. Khayyatzadeh S.S., Shafiee M., Far P.E., Ziaee S.S., Bagherniya M., Ebrahimi S., Boromand N., Ferns G.A., Ghayour-Mobarhan M. Adherence to a healthy dietary pattern is associated with less severe depressive symptoms among adolescent girls. Psychiatry Res. 2019;272:467-473. doi:10.1016/j.psychres.2018.12.164.

14. Kim T.H., Choi J.Y., Lee H.H., Park Y. Associations between Dietary Pattern and Depression in Korean Adolescent Girls. J Pediatr Adolesc Gynecol. 2015;28(6):533-537. doi: 10.1016/j.jpag.2015.04.005.

15. Kristjánsson A.L., Sigfúsdóttir I.D., Allegrante J.P. Health behavior and academic achievement among adolescents: the relative contribution of dietary habits, physical activity, body mass index, and selfesteem. Health Educ Behav. 2010;37(1):51-64. doi:10.1177/1090198107313481.

16. Merikangas K.R, He J.P., Burstein M., Swanson S.A., Avenevoli S., Cui L., Benjet C. Georgiades K., Swendsen $J$. Lifetime prevalence of mental disorders in U.S. adolescents: results from the National Comorbidity Survey Replication - Adolescent Supplement (NCS-A). J Am Acad Child Adolesc Psychiatry. 2010;49(10):980989. doi:10.1016/j.jaac.2010.05.017.

17. Oddy W.H., Allen K.L., Trapp G.S.A., Ambrosini G.L., Black L.J., Huang R.C., Rzehak P., Runions K.C., Pan F., Beilin L.J., Mori T.A. Dietary patterns, body mass index and inflammation: Pathways to depression and mental health problems in adolescents. Brain Behav Immun. 2018;69:428-439. doi:10.1016/j.bbi.2018.01.002..

18. Oddy W.H., Robinson M., Ambrosini G.L., O’Sullivan T.A., de KlerkN.H., Beilin L.J., Silburn S.R., Zubrick S.R., Stanley F.J. The association between dietary patterns and mental health in early adolescence. Prev Med. 2009;49(1):39-44. doi:10.1016/j.ypmed.2009.05.009.

19. Oleszko A., Szczepańska E., Janion K., Jośko-Ochojska $J$. Nutrition behaviours and the occurrence of depressive symptoms among the students in the institutions of higher education in Silesia (Poland). Rocz Panstw Zakl Hig. 2019;70(1):69-77.

20. O'Neil A., Quirk S.E., Housden S., Brennan S.L., Williams L.J., Pasco J.A., Berk M., Jacka F.N. Relationship between diet and mental health in children and adolescents: a systematic review. Am J Public Health. 2014;104(10):e31-42. doi:10.2105/AJPH.2014.302110.

21. Park S., Rim S.J., Lee J.H. Associations between dietary behaviours and perceived physical and mental health status among Korean adolescents. Nutr Diet. 2018;75(5):488-493. doi:10.1111/1747-0080.12444.

22. Stefańska E., Wendołowicz A., Kowzan U., Konarzewska B., Szulc A., Ostrowska L. Nutritional values of diets consumed by women suffering unipolar depression. Rocz Panstw Zakl Hig. 2014;65(2):139-145.

23. Tanaka M., Hashimoto $K$. Impact of consuming green and yellow vegetables on the depressive symptoms of junior and senior high school students in Japan. PLoS One. 2019;7;14(2):e0211323. doi:10.1371/journal. pone. 0211323 . 
24. Wattick R.A, Hagedorn R.L., Olfert M.D. Relationship between diet and mental health in a young adult Appalachian college population. Nutrients. 2018;25;10(8):957. doi: 10.3390/nu10080957.

25. Weng T.T., Hao J.H., Qian Q.W., Cao H., Fu J.L., Sun Y., Huang L., Tao F.B. Is there any relationship between dietary patterns and depression and anxiety in Chinese adolescents? Public. Health Nutr. 2012;15:673-682.

26. WHO. World Health Organization. Accelerating Country Action on Mental Health. Available: https:// www.who.int/mental_health/mhgap/Report_2018. pdf?ua $=1$ (Accessed 17.12.2019)

27. WHO, World Health Organization. Adolescent mental health in the European Region. Available: http://www. euro.who.int/ data/assets/pdf file/0005/383891/ adolescent-mh-fs-eng.pdf?ua=1 (Accessed 17.12.2019)

28. WHO. World Health Organization. Adolescent mental health. Available: https://www.who.int/news-room/ fact-sheets/detail/adolescent-mental-health (Accessed 17.12.2019)

29. Winpenny E.M., van Harmelen A.L., White M., van Sluijs E.M, Goodyer I.M. Diet quality and depressive symptoms in adolescence: no cross-sectional or prospective associations following adjustment for covariates. Public Health Nutr. 2018;21(13):23762384. doi:10.1017/S1368980018001179.

Received: 22.11.2019

Accepted: 20.12.2019 